\title{
Glutamate involvement in calcium-dependent migration of astrocytoma cells
}

\author{
Abdelkader Hamadi ${ }^{1}$, Grégory Giannone ${ }^{2^{*}}$, Kenneth Takeda ${ }^{1}$ and Philippe Rondé ${ }^{* *}$
}

\begin{abstract}
Background: Astrocytoma are known to have altered glutamate machinery that results in the release of large amounts of glutamate into the extracellular space but the precise role of glutamate in favoring cancer processes has not yet been fully established. Several studies suggested that glutamate might provoke active killing of neurons thereby producing space for cancer cells to proliferate and migrate. Previously, we observed that calcium promotes disassembly of integrin-containing focal adhesions in astrocytoma, thus providing a link between calcium signaling and cell migration. The aim of this study was to determine how calcium signaling and glutamate transmission cooperate to promote enhanced astrocytoma migration.

Methods: The wound-healing model was used to assay migration of human U87MG astrocytoma cells and allowed to monitor calcium signaling during the migration process. The effect of glutamate on calcium signaling was evaluated together with the amount of glutamate released by astrocytoma during cell migration.

Results: We observed that glutamate stimulates motility in serum-starved cells, whereas in the presence of serum, inhibitors of glutamate receptors reduce migration. Migration speed was also reduced in presence of an intracellular calcium chelator. During migration, cells displayed spontaneous $\mathrm{Ca}^{2+}$ transients. L-THA, an inhibitor of glutamate re-uptake increased the frequency of $\mathrm{Ca}^{2+}$ oscillations in oscillating cells and induced $\mathrm{Ca}^{2+}$ oscillations in quiescent cells. The frequency of migration-associated $\mathrm{Ca}^{2+}$ oscillations was reduced by prior incubation with glutamate receptor antagonists or with an anti- $\beta 1$ integrin antibody. Application of glutamate induced increases in internal free $\mathrm{Ca}^{2+}$ concentration $\left(\left[\mathrm{Ca}^{2+}\right]_{\mathrm{i}}\right)$. Finally we found that compounds known to increase $\left[\mathrm{Ca}^{2+}\right]_{\mathrm{i}}$ in astrocytomas such as thapsigagin, ionomycin or the metabotropic glutamate receptor agonist t-ACPD, are able to induce glutamate release.

Conclusion: Our data demonstrate that glutamate increases migration speed in astrocytoma cells via enhancement of migration-associated $\mathrm{Ca}^{2+}$ oscillations that in turn induce glutamate secretion via an autocrine mechanism. Thus, glutamate receptors are further validated as potential targets for astrocytoma cancer therapy.
\end{abstract}

Keywords: Glutamate release, Migration, U-87MG cell, Calcium spikes

\section{Background}

Primary brain neoplasm derived from glial cells account for more than $40 \%$ of all brain tumors. Among gliomas, astrocytomas represent the most common type of glial tumors and are generally associated with poor prognosis as these tumor cells often diffusely infiltrate neighboring brain structures by migrating along defined pathways such as blood vessels or myelinated nerves. This characteristic makes surgical resection rarely efficient because by

\footnotetext{
* Correspondence: gregory.giannone@u-bordeaux2.fr; philippe.ronde@unistra.fr ${ }^{2}$ Interdisciplinary Institute for Neuroscience and UMR CNRS 5297, University of Bordeaux, Bordeaux 33000, France

'Laboratoire de Biophotonique et Pharmacologie, CNRS, UMR 7213, Université de Strasbourg, Illkirch 67401, France
}

the time the primary tumor can be removed, secondary tumors may have already invaded the surrounding parenchyma. Hence, the aggressiveness of astrocytomas could be decreased by inhibiting cell migration, thereby confining the tumor in its original location.

Migration is a cellular process by which motile cells interact with different adhesion molecules presented by other cell types and extracellular matrix. Binding of adhesion proteins to their receptors generates signals that regulate cell proliferation and migration. A change in calcium homeostasis has been shown to represent one of the major intracellular signals implicated in the multiple and highly coordinated molecular events necessary to 
promote migration. For example, oscillations of intracellular $\mathrm{Ca}^{2+}$ modulate neuronal migration of growth cones $[1,2]$ and cerebellar granule cells [3]. Changes in intracellular $\mathrm{Ca}^{2+}$ have been reported to be responsible for persistent forward migration of neutrophils [4]. Several signaling pathways can be implicated in $\mathrm{Ca}^{2+}$ signaling observed during migration, including those mediated by adhesion receptors of the integrin family and those mediated by serum which could promote activation of the MAP kinase cascade $[5,6]$. Hence, in mouse fibroblasts, integrin engagement leads to phosphorylation of FAK and the subsequent conformation change promotes direct activation of PLC- $\gamma 1$ with the FAK autophosphorylation site Tyr-397, resulting in the generation of $\mathrm{IP}_{3}$ and release of $\mathrm{Ca}^{2+}$ from internal $\mathrm{Ca}^{2+}$ stores [7]. Previously, we demonstrated that in astroctytoma, increases in $\left[\mathrm{Ca}^{2+}\right]_{\mathrm{i}}$ are associated with increased phosphorylation of FAK at Tyr-397 [8].

The initial promoter of the $\mathrm{Ca}^{2+}$ signal appears to be cell type specific. In fish keratinocytes, integrin-dependent cell motion stimulates stretch-activated $\mathrm{Ca}^{2+}$-channels [9] whereas in arteriolar smooth muscle, integrin ligands modulate L-type $\mathrm{Ca}^{2+}$ channels [10]. In the developing brain, migration of immature neurons to their final destination is correlated with the expression of both $\mathrm{N}$-type $\mathrm{Ca}^{2+}$ channels and glutamate receptors. Moreover, the rate of movement of granule cells appears to be controlled by the activity of NMDA receptors [11]. In mice, glutamate serves as a chemoattractant for neurons in the developing cortex, signaling cells to migrate into the cortical plate via NMDA receptor activation [12]. In astrocytes, pharmacological blockade of NMDA receptors inhibits PSA-NCAM biosynthesis and dramatically diminishes cell migration from neurohypophyseal explants [13]. Nevertheless, the precise role of glutamate in mediating cell migration is not well understood, especially for glioma cells. For example, it has been described that glioma release large amounts of glutamate via both compromised glutamate transporters [14] and the cystine-glutamate exchange system $\mathrm{Xc}^{-}$[15]. The pathophysiological significance of elevated glutamate in the extracellular space has not been fully investigated, although it has been suggested that it might promote active neuronal cell death, thereby creating space for the growing tumor to expand [16] and enhancing glioma migration via activation of $\mathrm{Ca}^{2+}$-permeant AMPA receptors [17].

In this study, we investigated the role of glutamate in favoring glioma cell migration. We demonstrate that the human astrocytoma cell line U87MG is able to release glutamate in the extracellular space which in turn, activates glutamate receptors in an autocrine/ paracrine manner, thus leading to calcium signaling involved in both cell migration and enhanced glutamate release.

\section{Results}

Glutamate-enhanced migration of astrocytoma cells

Initially, using the wound-healing model of cell migration, we measured the migration speed of U87MG cells plated on matrigel-coated dishes. In the presence of $10 \%$ FCS the rate of migration was $470 \pm 3 \mu \mathrm{m} / 24 \mathrm{~h}$ and $251 \pm$ $4 \mu \mathrm{m} / 24 \mathrm{~h}$ in the absence of serum. Incubating the cells with the cell permeant $\mathrm{Ca}^{2+}$ chelator BAPTA/AM reduced serum-dependent migration while serum-independent migration was unchanged. This indicates the existence of a $\mathrm{Ca}^{2+}$-dependent migration process mediated at least in part by serum. In the absence of serum, addition of glutamate increased the rate of migration by $44 \%$ to $362 \pm 3 \mu \mathrm{m} / 24 \mathrm{~h}$, whereas in the presence of serum the rate of migration was unchanged by glutamate addition (Figure 1). Taken together, this suggests a role for glutamate and $\mathrm{Ca}^{2+}$ signaling in mediating cell motility. The decrease in migration observed for BAPTA-loaded cells likely involves a regulatory mechanism controlling the attachment of integrins to the substratum. We therefore compared the distribution pattern of $\beta_{1}$ integrins in migrating cells loaded or not with BAPTA. Buffering $\mathrm{Ca}^{2+}$ lead to the accumulation of $\beta_{1}$ integrins at the tail of the cell (Figure $1 \mathrm{C}$ ). Moreover, patches of integrin-containing structures were found at the rear of the cell, consistent with "ripping release", as the cell moved forward. This is consistent with changes in $\mathrm{Ca}^{2+}$ being necessary to promote the recycling of $\beta_{1}$ integrins from the tail of the cell.

\section{Migration of astrocytoma cells is associated with intracellular calcium oscillations}

The above results prompted us to further analyze the role of $\mathrm{Ca}^{2+}$ in migration. To do so, we used confocal imaging of intracellular $\mathrm{Ca}^{2+}$ in single migrating cells. In the presence of serum, $36 \%$ of cells displayed intracellular $\mathrm{Ca}^{2+}$ oscillations at varying frequencies during the 15 min observation period, whereas no spontaneous variations in $\mathrm{Ca}^{2+}$ were detected in the absence of serum (Figure 2A, B). To assess whether calcium oscillations were associated with migration, we tested a function-blocking antibody directed against $\beta_{1}$ integrins, one of the major integrins present in astrocytoma cells. For this purpose, cells were incubated with the anti- $\beta_{1}$ antibody $\mathrm{P} 4 \mathrm{C} 10$ prior to calcium measurements. In the presence of anti- $\beta_{1}$ antibody, a large decrease in the percentage of cells displaying $\mathrm{Ca}^{2+}$ transients was observed, up to $96 \%$, consistent with an essential role of integrin engagement in the generation of $\mathrm{Ca}^{2+}$ oscillations (Figure 2C). Of note, this antibody also significantly decreased the rate of migration of astrocytomas in the presence of serum by $73 \%$, with a mean value of $172 \pm 4 \mu \mathrm{m} / 24 \mathrm{~h}(\mathrm{n}=4)$. 

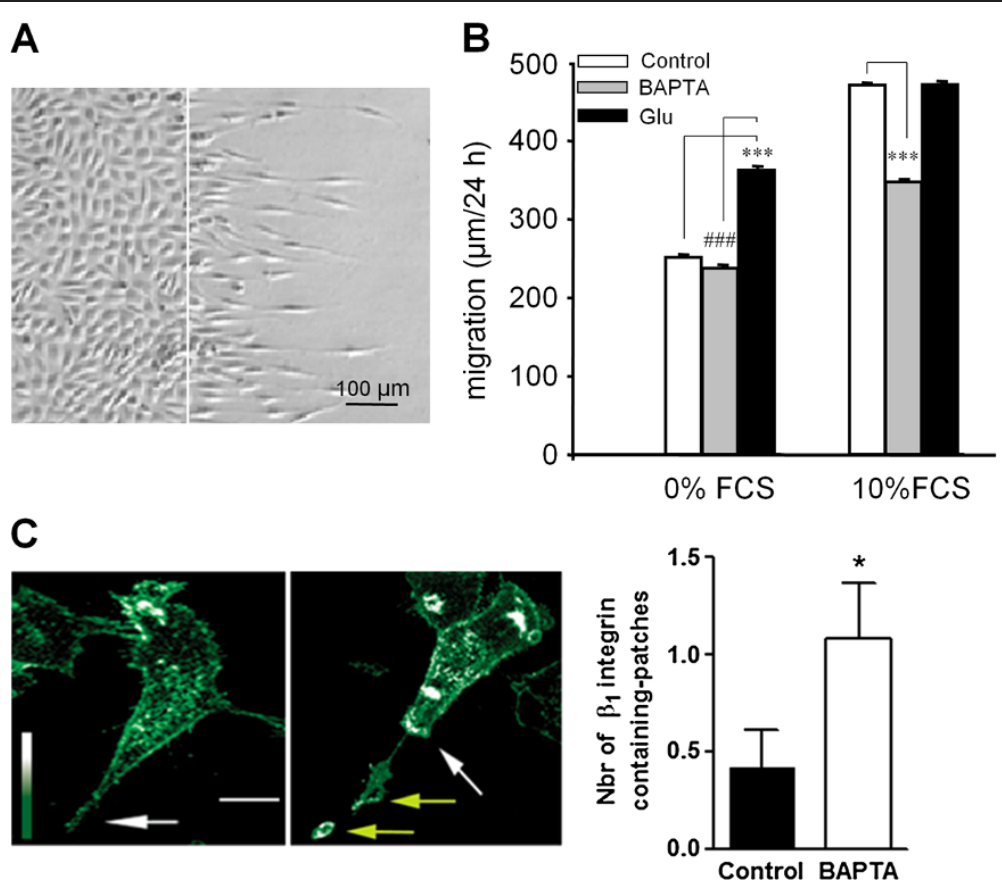

Figure 1 Glutamate increases motility in astrocytoma cells. A: Representative field showing U-87MG cells plated on Matrigel-coated dishes after 24 hours of migration in a wound healing model of migration (the white line indicates the border of the lesion). B: The speed of migration of U-87MG cells plated on matrigel-coated dishes was measured $24 \mathrm{~h}$ after lesion. The presence of $10 \%$ fetal calf serum (FCS) in the culture medium increases the rate of migration by 51\%. Serum-dependent migration is reduced by 55\% when the cells were first loaded for 30 minutes with $20 \mu \mathrm{M}$ BAPTA-AM to chelate intracellular $\mathrm{Ca}^{2+}$. Glutamate increased serum-independent migration while serum-dependent migration was left unchanged. Data are mean \pm SEM; $n=4$ independent experiments with 120 to 240 cells analyzed per condition; ${ }^{* * *} p<0.001$. C: Cells loaded or not with $20 \mu \mathrm{M}$ BAPTA, were allowed to migrate on Matrigel-coated glass coverslips and then immunostained with the anti- $\beta_{1}$ integrin antibody. White arrows indicate the cellular tail and yellow arrows, patches of $\beta_{1}$ integrin. Scale bar, $20 \mu \mathrm{m}$. The number of patches of $\beta_{1}$ integrin-containing structures found at the rear of the cell was quantified in control and BAPTA-loaded cells. Data are mean \pm SEM of 3 independent experiments with 4 fields analyzed per experiment.

\section{$\mathrm{Ca}^{2+}$-mobilizing agents induce glutamate release from astrocytoma cells}

It is well described that gliomas and astrocytomas release large amounts of glutamate in the medium as compared to non cancer cells [14]. Moreover, it has been previously shown that glioma invasion may be promoted via an autocrine glutamate signaling loop [17]. The release of glutamate by glioma/astrocytoma cells could be both $\mathrm{Ca}^{2+}$-dependent and $\mathrm{Ca}^{2+}$-independent. Therefore, as U87MG cell migration is associated with calcium oscillations and augmented in the presence of glutamate, we tested whether compounds known to increase $\left[\mathrm{Ca}^{2+}\right]_{i}$ were able to induce release of glutamate from U87MG cells. For this purpose, we used an enzymatic assay to continuously monitor the release of glutamate in migrating cells plated on matrigel-coated coverslips in order to keep the same experimental conditions as those used to measure the speed of migration and changes in $\left[\mathrm{Ca}^{2+}\right]_{i}$. We first used two compounds, thapsigagin and ionomycin, known to promote large increases in $\left[\mathrm{Ca}^{2+}\right]_{i}$ in these cells [18]. As shown in Figure 3, both thapsigargin and ionomycin were able to produce glutamate release. Moreover,
t-ACPD, an agonist of metabotropic glutamate receptors which has been shown to provoke increases in $\left[\mathrm{Ca}^{2+}\right]_{i}$ in astrocytes $[19,20]$ also induced glutamate release. On the other hand, we were unable to observed glutamate release using specific agonists of NMDA and AMPA/kainate glutamate receptor subtypes (data not shown).

\section{Glutamate increases intracellular $\mathrm{Ca}^{2+}$ levels}

As most glutamate receptors are known to alter calcium homeostasis, we designed experiments to test whether glutamate was involved in migration-associated $\mathrm{Ca}^{2+}$ oscillations using Fura-2 imaging of intracellular $\mathrm{Ca}^{2+}$ in single migrating cells. Addition of glutamate $(1 \mu \mathrm{M}$ $1 \mathrm{mM}$ ) in replacement of serum did not mimic the effect of serum as in the majority of the cells, no oscillation of $\left[\mathrm{Ca}^{2+}\right]_{i}$ could be detected during the migration process (data not shown). Nevertheless, addition of $300 \mu \mathrm{M}$ glutamate produced a sharp increase in $\left[\mathrm{Ca}^{2+}\right]_{i}$. In $85 \%$ of the cells, the increase in $\left[\mathrm{Ca}^{2+}\right]_{i}$ resulted in a single transient of $\mathrm{Ca}^{2+}$ whereas in the other $15 \%$, oscillations of small amplitude were detected following the initial response (Figure $4 \mathrm{~A}$ ). The increase in $\left[\mathrm{Ca}^{2+}\right]_{i}$ was dose- 

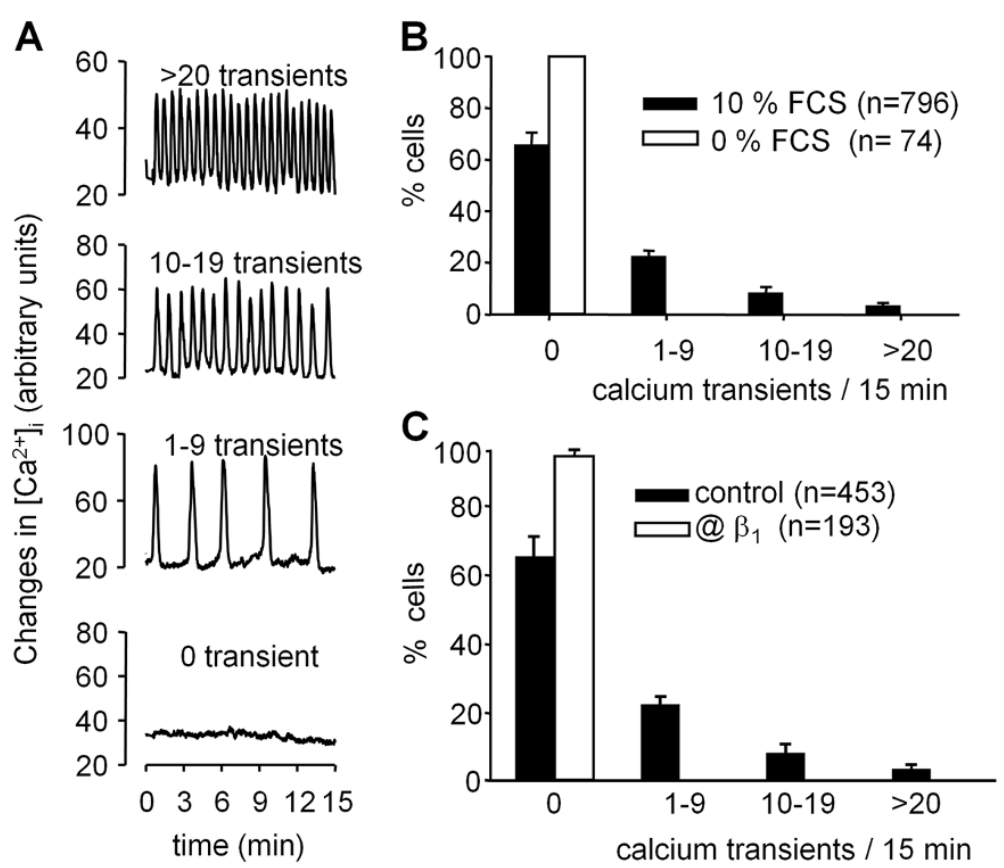

Figure 2 Migrating astrocytoma cells exhibit serum-dependent intracellular $\mathrm{Ca}^{2+}$ oscillations at varying frequencies. A: Cells plated on Matrigel-coated glass-coverslips were loaded with Oregon green and observed using a confocal microscope. Representative traces of individual cells show a varying number of spontaneous intracellular $\mathrm{Ca}^{2+}$ transients. Cells were grouped according to the number of intracellular $\mathrm{Ca}^{2+}$ transients displayed during the 15 minutes acquisition period. B: The percentage of cells displaying 0, 1-9, 10-19 and $>20$ intracellular $\mathrm{Ca}^{2+}$ transients during 15 minutes, in the presence or absence of $10 \%$ FCS. C: The percentage intracellular $\mathrm{Ca}^{2+}$ transients during 15 minutes, in the presence or absence of the functional antibody P4C10 directed against $\beta 1$ integrins. Data are mean \pm SEM of 4 independent experiments, $n$ indicate the number of cells analyzed per conditions.

dependent with an $\mathrm{EC}_{50}$ of $284 \pm 16 \mu \mathrm{M}$ and a maximum increase of $210 \pm 26 \mathrm{nM} \mathrm{Ca}^{2+}$ (Figure 4B).

\section{Glutamate reuptake inhibitor induces increased migration-associated $\mathrm{Ca}^{2+}$ oscillations}

Because addition of glutamate in the absence of serum did not induce $\mathrm{Ca}^{2+}$ oscillations comparable to those observed in the presence of serum, we tested whether glutamate could enhance serum-mediated $\mathrm{Ca}^{2+}$ oscillations. As it is difficult to estimate the concentration of glutamate present in the medium, we chose to increase

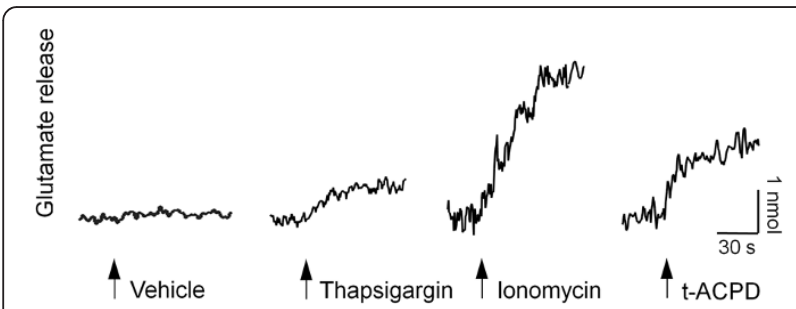

Figure $3 \mathrm{Ca}^{2+}$ mobilizing agents induced glutamate release in astrocytoma cells. Fluorescence traces representing glutamate release elicited by vehicle (far left) thapsigargin (left), an inhibitor of the endoplasmic reticulum $\mathrm{Ca}^{2+}$ ATPase, ionomycin (right), a $\mathrm{Ca}^{2+}$ ionophore, and $\mathrm{t}-\mathrm{ACPD}$ (far right), a selective metabotropic glutamate receptor agonist. The traces are representative for 4-6 independent experiments. the concentration of glutamate in the extracellular medium by inhibiting the reuptake of glutamate. In agreement with our previous result, in the presence of serum, $36 \%$ of the cells displayed intracellular $\mathrm{Ca}^{2+}$ oscillations at varying frequencies during the $15 \mathrm{~min}$ observation period. Addition of $100 \mu \mathrm{M} \mathrm{L}(-)$-threo-3-hydroxyaspartic acid, a potent inhibitor of both glial and neuronal uptake of glutamate [21] produced a two-fold increase in the frequency of $\mathrm{Ca}^{2+}$ oscillations. Analyzing in further detail the complex pattern of behavior of L-THA-treated cells, we observed that in $30 \%$ of the cells, L-THA had no effect whereas in $39 \%$, L-THA caused an increase in $\mathrm{Ca}^{2+}$ oscillation frequency (Figure $5 \mathrm{~A}$ ) and in the remaining $31 \%$, L-THA initiated oscillatory $\mathrm{Ca}^{2+}$ behavior in cells which did not display spontaneous variations of $\left[\mathrm{Ca}^{2+}\right]_{i}$ before addition of the compound (Figure 5B). Taken together, these results suggest that glutamate present in the serum and/or released by the cells is able to alter $\mathrm{Ca}^{2+}$ homeostasis, thereby contributing to enhanced migration.

\section{Glutamate antagonists reduce migration and} migration-associated $\mathrm{Ca}^{2+}$ oscillations

As glutamate increases cell migration and $\mathrm{Ca}^{2+}$ oscillation frequency, we tested whether the serum-dependent 


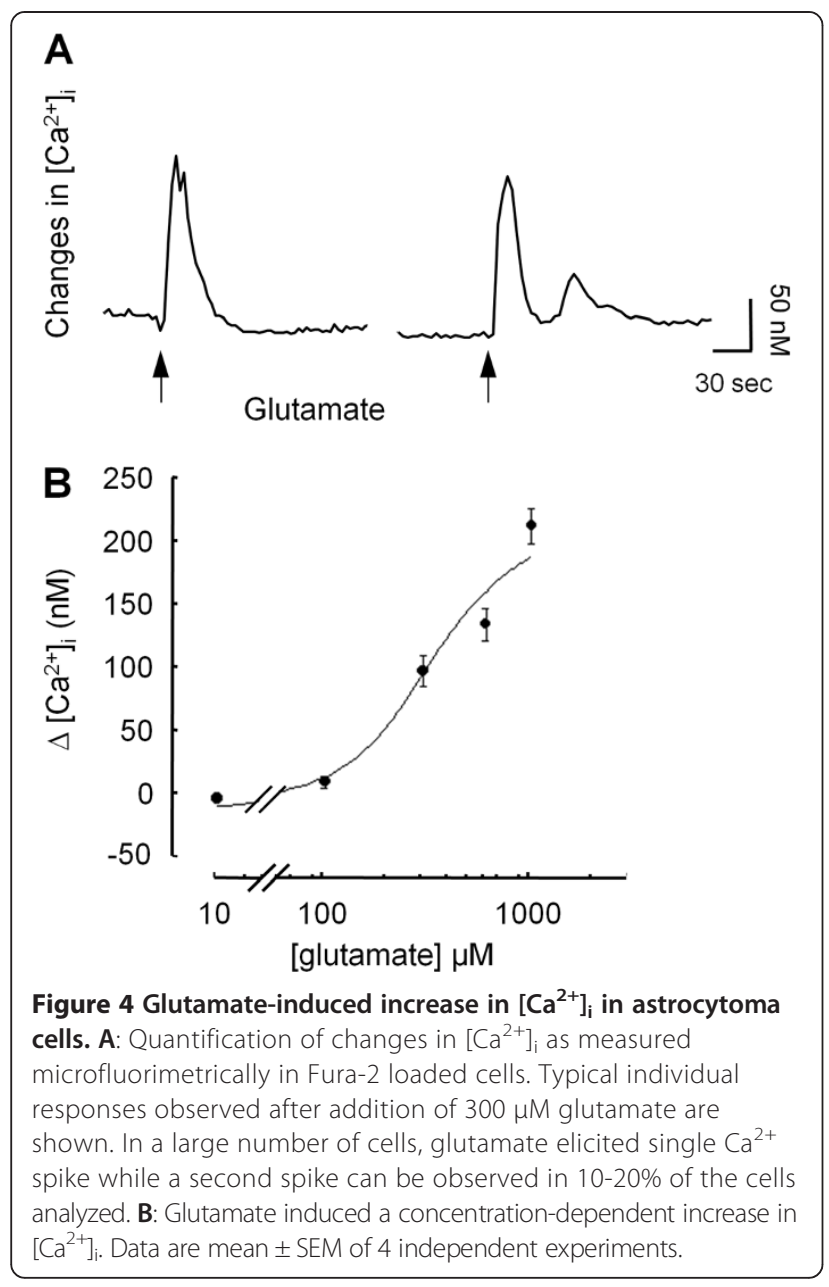

component of the migration process is mediated at least in part by glutamate acting at glutamate receptors. Selective antagonists at NMDA receptors, MK801 [22], kainate receptor, CNQX [23] and a large spectrum antagonist at metabotropic receptor, AP3 [24] were added in the culture medium supplemented or not with $10 \%$ serum after the lesion was achieved. As shown in Figure 6, all antagonists reduced significantly serum-dependent migration. Migration was reduced by $24 \%$ in the presence of $10 \mu \mathrm{M}$ MK801, 53\% in the presence of CNQX and 85\% in the presence of AP3. On the other hand, all three compounds were without effect on the serum-independent component of migration. This is consistent with glutamate receptors being involved in serum-mediated migration. Next, we determined which type of glutamate receptor was involved in the oscillations of $\left[\mathrm{Ca}^{2+}\right]_{i}$ observed during migration. For this purpose, U87MG cells displaying oscillatory behavior were incubated for $30 \mathrm{~min}$ with antagonists of various glutamate receptor subtypes and the numbers of $\mathrm{Ca}^{2+}$ spikes were compared before and after treatment. Addition of $10 \mu \mathrm{M}$ MK801 slightly but

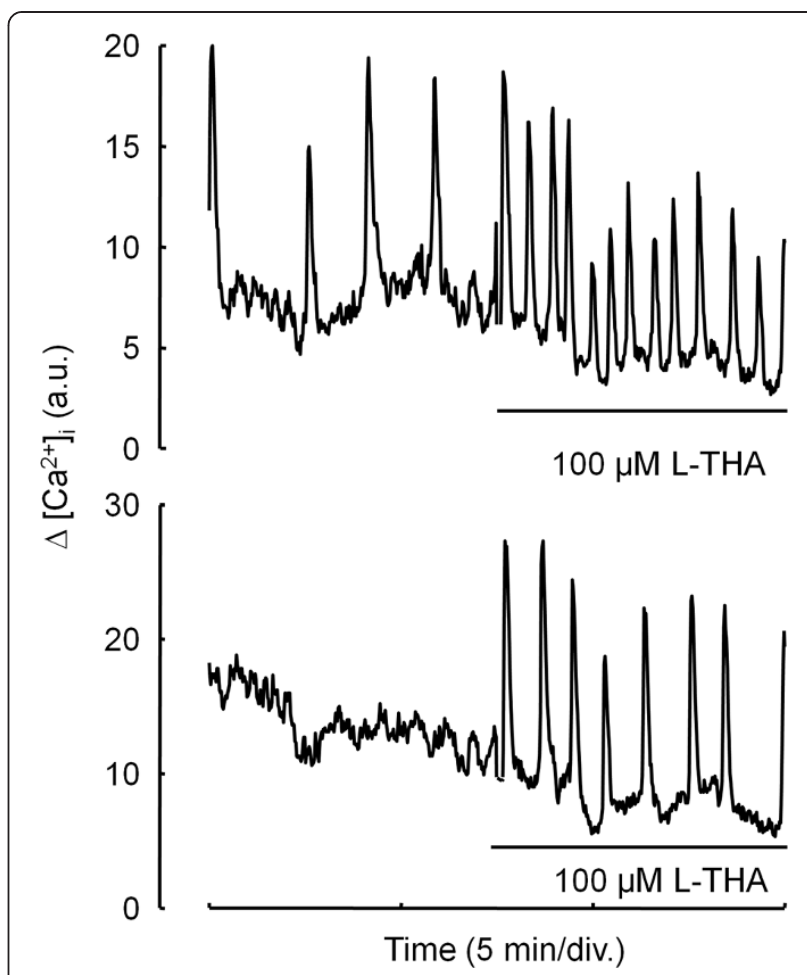

Figure $\mathbf{5}$ Inhibition of glutamate reuptake induced increase in $\mathrm{Ca}^{2+}$ oscillations frequency. Fluo-3 loaded cells were allowed to migrate on Matrigel-coated glass coverslips and changes in fluorescence were measured at $522 \mathrm{~nm}$ using confocal microscopy before and after addition of $100 \mu \mathrm{M}$ L-THA. Top: Typical individual response of spontaneous $\mathrm{Ca}^{2+}$ oscillations is presented. Note the increase in spontaneous $\mathrm{Ca}^{2+}$ oscillations frequency after addition of L-THA. Bottom: In non oscillating, quiescent cells, addition of L-THA induced $\mathrm{Ca}^{2+}$ oscillations as measured by changes in fluo-3 fluorescence. Data are mean \pm SEM of 4 independent experiments with 67 cells analyzed per condition.

significantly reduced the number of $\mathrm{Ca}^{2+}$ spikes. In contrast, addition of $10 \mu \mathrm{M}$ CNQX resulted in a $60 \%$ inhibition of the number of $\mathrm{Ca}^{2+}$ spikes and $100 \mu \mathrm{M}$ AP3 caused a $78 \%$ decrease in $\mathrm{Ca}^{2+}$ oscillation frequency (Figure 7). The order of potency of these compounds is in agreement with their respective abilities to inhibit serum-mediated migration and highlights the close relationship existing between migration and $\mathrm{Ca}^{2+}$ oscillation behavior in these cells $[8,25]$.

\section{Discussion}

In this study, we have demonstrated that glutamate released by human astrocytoma cells contributes to enhanced migration by a mechanism involving glutamateassociated $\mathrm{Ca}^{2+}$ oscillations. Indeed, antagonists of glutamate receptors inhibit both cell migration and migration-associated $\mathrm{Ca}^{2+}$ oscillations while glutamate itself stimulates migration under serum deprivation. Moreover, the glutamate reuptake inhibitor L-THA increases the frequency of $\mathrm{Ca}^{2+}$ oscillations and induces 


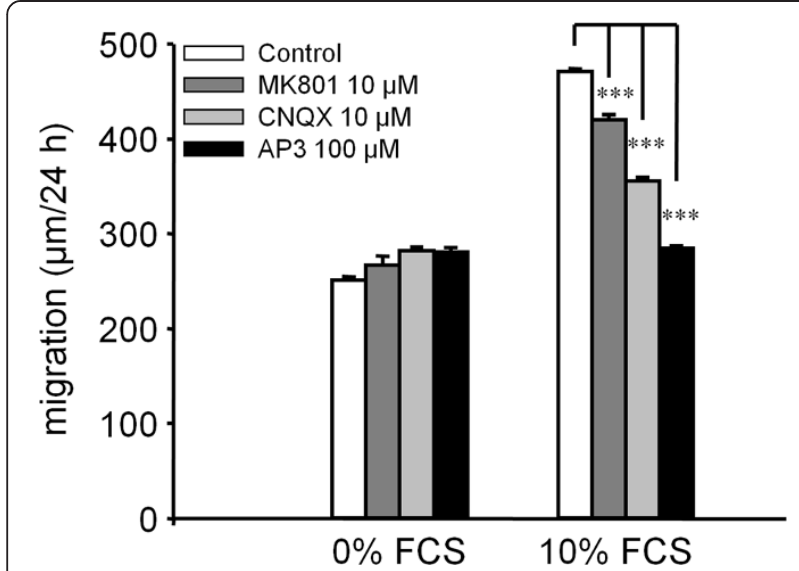

Figure 6 Glutamate antagonists reduced astrocytoma cell migration. In the absence of serum, glutamate antagonists had no effect on the speed of migration while in the presence of serum, migration was significantly reduced, the major effect being observed using AP3 an antagonist at metabotropic glutamate receptor. Data are mean $\pm S E M ; n=4$ independent experiments with 50 to 240 cells analyzed per condition; ${ }^{* * *} p<0.001$

$\mathrm{Ca}^{2+}$ oscillations in quiescent cells. These effects can be correlated with the inhibitory action of the $\mathrm{Ca}^{2+}$ chelator BAPTA on the migration of these cells.

$\mathrm{Ca}^{2+}$-dependent migration was first demonstrated in neutrophils where the speed of migration and persistent forward motion were correlated with intracellular $\mathrm{Ca}^{2+}$ levels [26]. In cerebellar microexplant cultures, while a global increase in intracellular $\mathrm{Ca}^{2+}$ was not correlated with cell mobility, it was rather found that the frequency and amplitude of $\mathrm{Ca}^{2+}$ fluctuations control the rate of migration of granule cells [3]. Moreover, granule cells start their radial migration only after the expression of $\mathrm{N}$-type $\mathrm{Ca}^{2+}$ channels and glutamate receptors on the plasmalemmal surface [27] supporting the idea that glutamate receptors associated with $\mathrm{Ca}^{2+}$ signaling may be a key component of cellular migration. Similarly, we reported that the migration of smooth muscle cells and U87MG cells were dependent upon oscillations of intracellular $\mathrm{Ca}^{2+}[18,28]$. The role of glutamate and $\mathrm{Ca}^{2+}$ in regulating proliferation and migration of neurons during development is now well recognized but little is known concerning whether glutamate alters proliferation and migration of tumor cells. Several studies have shown that glutamate antagonists limit tumor growth of various human tumor cells, including astrocytoma $[29,30]$. The mechanisms implicated in this anti-cancer effect involve both a decrease in tumor cell proliferation and a reduction of cell motility. Interestingly, the anti-proliferative effect of glutamate antagonists was $\mathrm{Ca}^{2+}$ dependent and resulted from decreased cell division and increased cell death. Nevertheless, the molecular events involved in the reduction of tumor cell locomotion and invasiveness

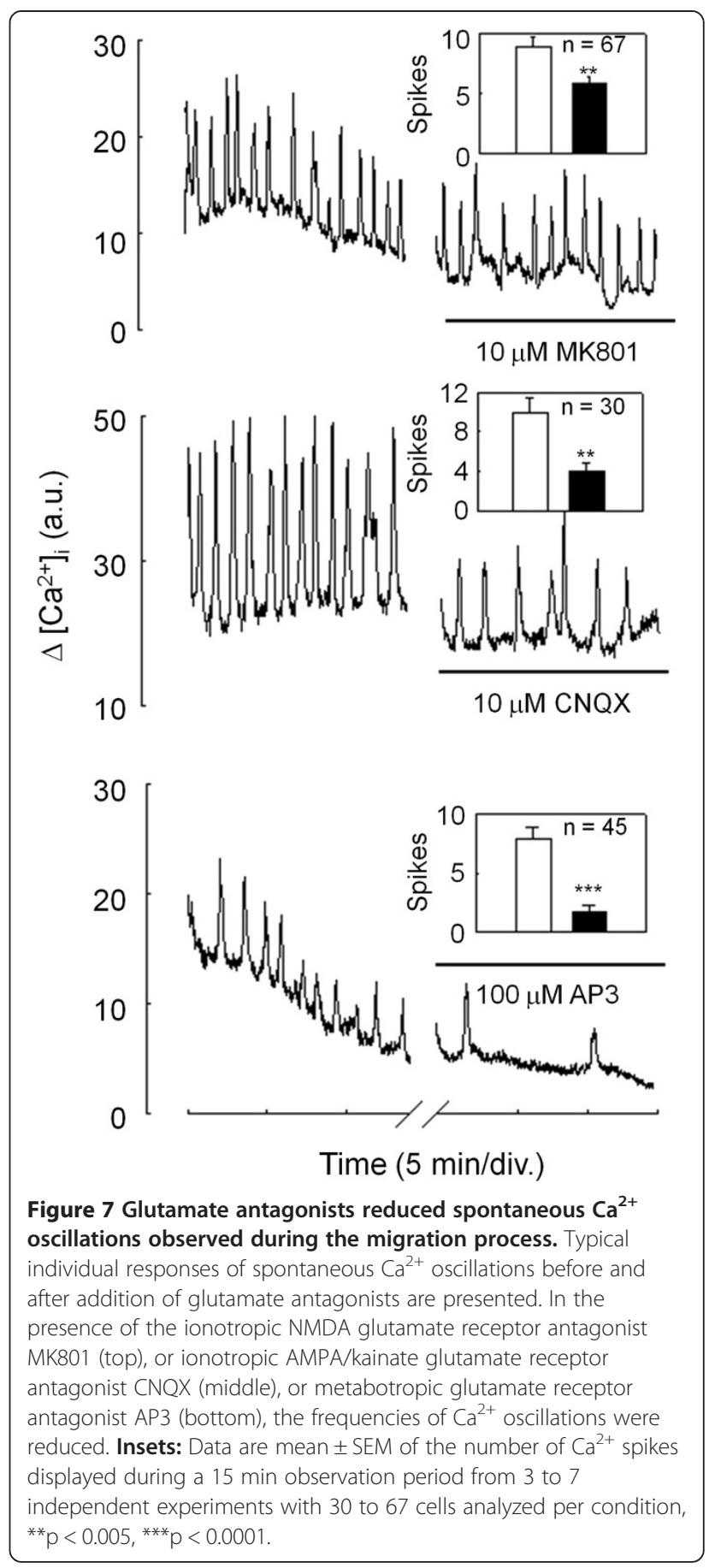

have not been described. Our study demonstrates that glutamate antagonists limit migration of astrocytoma cells by a mechanism involving a reduction in $\mathrm{Ca}^{2+}$ signaling, as found for neuronal progenitors during embryogenesis [3]. Taken together, these data suggest that glutamate antagonists possess anti-cancer potential because they may promote both anti-proliferative and anti-motility effects. 
How a decrease in glutamate-mediated $\mathrm{Ca}^{2+}$ signaling is able to reduce cell motility is an interesting question. Calcium oscillations are associated with different processes crucial for cell invasion like cell polarization [31], focal adhesion turnover [8] or regulation of metalloproteinases [32]. Many reports have shown that $\mathrm{Ca}^{2+}$ can alter the affinity between adhesion receptors and their specific extracellular ligands on the extracellular matrix [33-35] thereby providing a means to regulate migration. Indeed, in the presence of an intracellular $\mathrm{Ca}^{2+}$ chelator such as BAPTA, both human smooth muscle cells [28] and astrocytoma [8] have reduced migration. The underlying mechanisms may involve altered recycling of adhesion proteins [36] or altered disassembly of focal adhesion sites [25]. This may be due to reduced activities of $\mathrm{Ca}^{2+}$-dependent proteases implicated in focal adhesion protein degradation of for example, calpain [37-39] or calcineurin [40]. One of the major proteins involved in focal adhesion recycling during migration is FAK. Reduced cell motility and enhanced focal adhesion contact formation has been shown in cells from FAK-deficient mice [41]. It is now well accepted that activation of FAK promotes migration whereas inhibition of FAK or altered FAK phosphorylation decrease migration [42-46]. Several reports point out the role of glutamate receptors in the activation of FAK in a $\mathrm{Ca}^{2+}$ dependent manner. For example, glutamate and specific agonists of ionotropic and metabotropic glutamate receptors stimulate phosphorylation of FAK in hippocampal slices or cortical synaptosomes [47]. In high-grade glioma, AMPA receptors promotes perivascular invasion via integrins and FAK activation [48]. Moreover, glutamate stimulates phospholipase $\mathrm{C}$ and phosphorylation of FAK in $\mathrm{CHO}$ cells expressing mGluR1 receptors. Phosphorylation of FAK was reduced by PLC inhibitors or by depletion of intracellular $\mathrm{Ca}^{2+}$, consistent with a link between mGluR1 receptors, $\mathrm{Ca}^{2+}$ and FAK activation [49]. In our study, the respective order of potency of glutamate antagonists suggests that metabotropic glutamate receptors are the main receptor implicated in the $\mathrm{Ca}^{2+}$-dependent migration process observed in astrocytoma cells. This is not surprising in view of the role of mGluR1 in FAK activation, the major role of metabotropic glutamate receptors in astrocytes and the pattern of $\mathrm{Ca}^{2+}$ oscillations observed in U87MG cells which is consistent with activation of mGluR1 receptors.

Next, the question arises as to know which pool of glutamate is responsible for the enhanced migration observed in the presence of glutamate. Because migration and $\mathrm{Ca}^{2+}$ oscillatory behavior of these cells were dependent upon serum, it is possible that glutamate present in the serum is sufficient to account for these effects. Indeed, addition of 10\% FCS in culture medium or in PBS produced a large increase in NADPH fluorescence due to formation of $\alpha$-ketoglutarate, consistent with the presence of glutamate in FCS (not shown). In the presence of $10 \%$ FCS, addition of glutamate did not further enhance migration (Figure 2). Since the $\mathrm{Ca}^{2+}$ oscillation pattern observed during migration was quite diverse, this suggests that glutamate concentration in the cellular environment is closely regulated, probably involving controlled release and/or reuptake of glutamate. Indeed, in the presence of a glutamate reuptake inhibitor, the $\mathrm{Ca}^{2+}$ oscillation frequency of our cells was increased 2 -fold.

The mechanism responsible for glutamate release from astrocytes has been the subject of controversy for some time. Evidence for both $\mathrm{Ca}^{2+}$-dependent and -independent mechanisms has been reported. The $\mathrm{Ca}^{2+}$-dependent mechanism is an exocytotic process similar to that observed in neurons $[50,51]$, whereas the $\mathrm{Ca}^{2+}$-independant mechanism may involve swelling-dependent mechanisms [52], alteration or reversion of glutamate transporters $[15,16,53]$ and up-regulation of the cystine-glutamate exchange system $\mathrm{Xc}^{-}[15,17]$. $\mathrm{Ca}^{2+}$-dependent release of glutamate in astrocytes represents a major pathway for intercellular communication. For example, elevation of intracellular $\mathrm{Ca}^{2+}$ in astrocytes was both necessary and sufficient to induce an increase in miniature postsynaptic currents in cultured hippocampal neurons, an effect prevented by the NMDA receptor antagonist AP5, consistent with release of glutamate from astrocytes [51]. Extracellular waves of glutamate were imaged during $\mathrm{Ca}^{2+}$ signaling in cultured astrocytes [54]. Finally, glutamate mediates calcium oscillations in astrocytes leading to the release of other transmitters like prostaglandin [55]. In our study, compounds that mobilize intracellular calcium store, like thapsigargin or t-ACPD, an agonist of the metabotropic glutamate receptors, stimulate glutamate release (Figure 3). This agrees with previous studies showing that $\mathrm{Ca}^{2+}$-dependent release of glutamate involves intracellular $\mathrm{Ca}^{2+}$ stores in astrocytes [56,57] and with the expression of metabotropic receptors in both astrocytes and astrocytomas [58,59]. Of note, in astrocytomas, glutamate release and reuptake mechanisms appear deeply altered. For example, although one of the major role of astrocytes is to protect neuron from an excess of glutamate via high capacity reuptake systems [60], astrocytomas release large amounts of glutamate which result in elevated external glutamate concetrations, up to $100 \mu \mathrm{M}$ [14]. In our cells, the glutamate reuptake inhibitor L-THA enhanced calcium oscillations (Figure 5). As L-THA is a substrate inhibitor and therefore, being transported by the glutamate transporter in place of glutamate [61], the increase in $\mathrm{Ca}^{2+}$ signaling observe upon L-THA addition indicates that glutamate transporters are at least partially functional in U87MG cells. The ability of L-THA to either increase the frequency of $\mathrm{Ca}^{2+}$ oscillations or to induce $\mathrm{Ca}^{2+}$ oscillations 
in quiescent cells suggests that at least in part, alteration of glutamate transporters is responsible for $\mathrm{Ca}^{2+}$-mediated migration of astrocytoma cells.

\section{Conclusion}

Our study uncovers an autocrine glutamate signaling loop whereby altered glutamate reuptake leads to enhanced glutamate release from astrocytoma cells and subsequent activation of glutamate receptors, particularly the metabotropic subtypes. This in turn activates calcium signaling further promoting glutamate release. Finally, $\mathrm{Ca}^{2+}$ oscillations induce FAK phosphorylation and focal adhesion disassembly as we already reported in this cell line [8], thus leading to enhanced migration.

\section{Methods}

\section{Materials}

Cell culture medium (EMEM), fetal calf serum (FCS), HEPES, L-glutamine, penicillin, streptomycin, gentamycin and trypsin-EDTA solution (0.5 g/l trypsin/0.2 g/l EDTA) were from Gibco. Glutamate, CNQX, AP3 MK801 and L-(-)-threo-3-Hydroxyaspartic acid were from Tocris. Glutamate deshydrogenase and $\mathrm{NADP}^{+}$were from Sigma. Oregon Green 488 BAPTA-1 acetoxylmethylester (AM), Fura-2/AM, BAPTA/AM and Pluronic acid F-127 were from Molecular Probes.

\section{Cell culture}

The human astrocytoma cell line U87MG was obtained from the American Type Culture Collection. Cells were maintained in $5 \% \mathrm{CO}_{2}$ in air at $37^{\circ} \mathrm{C}$ in a humidified incubator on type I collagen $(0.06 \mathrm{mg} / \mathrm{ml})$-coated plastic dishes in EMEM supplemented with $10 \%$ heat-inactivated FCS, $0.6 \mathrm{mg} / \mathrm{ml}$ glutamine, $200 \mathrm{IU} / \mathrm{ml}$ penicillin, $200 \mathrm{IU} / \mathrm{ml}$ streptomycin and $0.1 \mathrm{mg} / \mathrm{ml}$ gentamycin.

\section{Migration assay}

U-87MG were seeded onto $35 \mathrm{~mm}$ diameter Petri dishes coated with Matrigel $(178 \mu \mathrm{g} / \mathrm{ml})$ and grown to confluence in a $37^{\circ} \mathrm{C}$ incubator gassed with $5 \% \mathrm{CO}_{2}$ in air. After $24 \mathrm{~h}$ of serum starvation, a rectangular lesion was created using a cell scraper and cells were rinsed 3 times with culture medium containing or not $10 \%$ FCS. The cells were then incubated with the respective experimental medium supplemented or not with the compound to be tested. After $24 \mathrm{~h}$ of migration, 3 randomly selected fields at the lesion border were acquired using a $10 \mathrm{x}$ phase objective on an inverted microscope (Olympus IMT2) equipped with a CCD camera (Panasonic). In each field, the distance between the margin of the lesion and the most distant point on migrating cells was analyzed for the 10 most mobile cells. Control experiments were made in presence of vehicle, typically water or DMSO at $\leq 0.01 \%$. Analysis was made using the Image
Tool program (University of Texas Health Science Center at San Antonio; available by FTP from maxrad6. uthscsa.edu). For experiments with BAPTA/AM, cells were loaded for $45 \mathrm{~min}$ with $20 \mu \mathrm{M}$ BAPTA/AM and $0.03 \%$ Pluronic acid F-127 in a $37^{\circ} \mathrm{C}$ incubator gassed with $5 \% \mathrm{CO}_{2}$ in air prior to the creation of lesions and washing.

\section{Cytosolic free calcium measurements}

For intracellular calcium measurements during migration, cells were cultured at subconfluence on Petri dishes in which a $2 \mathrm{~cm}$ diameter hole had been cut in the base and replaced by a thin $(0.07 \mathrm{~mm})$ glass coverslip coated with Matrigel. Experiments were performed $48 \mathrm{~h}$ or $72 \mathrm{~h}$ after plating. Cells were incubated for $45 \mathrm{~min}$ with the fluorescent $\mathrm{Ca}^{2+}$ indicator Oregon Green 488 BAPTA-1 acetoxylmethylester $(5 \mu \mathrm{M})$ in culture medium containing $0.03 \%$ Pluronic acid F-127 in a $37^{\circ} \mathrm{C}$ incubator gassed with $5 \% \mathrm{CO}_{2}$ in air. Cells were then washed twice with an external solution (in mM: $140 \mathrm{NaCl}, 5 \mathrm{KCl}, 2 \mathrm{CaCl}_{2}$, $2 \mathrm{MgCl}_{2}, 10$ HEPES and 11 glucose, $\mathrm{pH}$ 7.4) before $\mathrm{Ca}^{2+}$ measurements. Imaging was done at $30^{\circ} \mathrm{C}$ in external solution, with or without the compounds to be tested, using a Bio-Rad MRC-1024 laser-scanning confocal system and an inverted microscope (Nikon Eclipse) using a $40 \times$ oil-immersion epifluorescence objective (n.a. 1.4, Nikon). Emitted fluorescence was measured at $535 \pm$ $10 \mathrm{~nm}$ in response to $488 \mathrm{~nm}$ excitation from a krypton/ argon laser, with images being usually acquired at $1 \mathrm{~s}$ intervals during a 15 min period. In experiments measuring intracellular calcium concentrations, cells were incubated for $30 \mathrm{~min}$ at $37^{\circ} \mathrm{C}$ in a Ringer containing $5 \mu \mathrm{M}$ Fura-2/acetoxylmethylester (Fura-2/AM). Cells were then washed for $15 \mathrm{~min}$ at $37^{\circ} \mathrm{C}$ with Ringer solution. Digital imaging was performed at room temperature using an IMSTAR (Paris, France) imaging system. Small groups of dispersed cells were viewed using an inverted microscope (Nikon Diaphot, Tokyo, Japan) and an UV-fluor 20x objective (n.a. 0.75, Nikon). Fura-2 fluorescence was excited alternately at 340 and $380 \mathrm{~nm}$, using bandpass filters ( $\pm 10 \mathrm{~nm}$, Nikon) and a $100 \mathrm{~W}$ mercury lamp (HBO, Osram). Emitted fluorescence was bandpass filtered at $510 \pm 20 \mathrm{~nm}$ (Nikon) and measured using a Darkstar-800 CCD Camera (Photonics Sciences, Milham, UK). Acquired images were analyzed with the fluo 210 IMSTAR software. Ratiometric $\mathrm{Ca}^{2+}$ images were generated at $5 \mathrm{~s}$ intervals, using 4 averaged images at each wavelength. After background compensation, $\left[\mathrm{Ca}^{2+}\right]_{\mathrm{i}}$ was averaged from pixels within manually outlined regions of interest corresponding to each cell. $\left[\mathrm{Ca}^{2+}\right]_{\mathrm{i}}$ values were calculated as described elsewhere (Grynkiewicz et al., 1985). Control experiments were made in presence of vehicle, typically water or DMSO at $\leq 0.01 \%$. 


\section{Immunocytochemistry}

Cells treated or not with $20 \mu \mathrm{M}$ BAPTA-AM for $30 \mathrm{~min}$, were allowed to migrate for $24 \mathrm{~h}$ before immunostaining. After 15 min fixation in $4 \%$ paraformaldehyde in PBS, cells were incubated $1 \mathrm{~h}$ with the anti- $\beta_{1}$ integrin antibody $\mathrm{P} 4 \mathrm{C} 10(1 / 400, \mathrm{~V} / \mathrm{V})$ in $\mathrm{PBS}$, and then with a FITC-conjugated goat anti-mouse secondary antibody (Zymed) for $1 \mathrm{~h}$. Confocal images of migrating cells were obtained as described above, with Z-series being collected in $1 \mu \mathrm{m}$ steps. Analysis was done after stacking the first 6 images corresponding to the basal, matrix-associated sections of the cell. The number of patches of $\beta_{1}$ integrin-containing structures found at the rear of the cell was quantified in control and BAPTA-loaded cells.

\section{Enzymatic assay of endogenous glutamate release}

Confluent U-87MG cells plated on glass cover slips were lodged in a $1 \times 1 \mathrm{~cm}$ cuvette containing Ringer's solution supplemented with glutamate deshydrogenase $(40 \mathrm{U} / \mathrm{ml})$ and $1 \mathrm{mM} \mathrm{NADP}^{+}$inside a Hitachi 2000 computerized spectrofluorimeter at $37^{\circ} \mathrm{C}$ under stirring. Glutamate released from the preparation was immediately oxidized by GDH to $\alpha$-ketoglutarate with formation of NADPH and fluorescence emission at $430 \mathrm{~nm}$ (delay <1 s; excitation at $335 \mathrm{~nm}$ ). Release was quantified using standard curves constructed with exogenous addition of glutamate from $0.1 \mu \mathrm{M}$ to $1 \mathrm{mM}$. Agents were added directly in the cuvette using a microsyringe. In experiments using BAPTA/AM, cells were first incubated for $45 \mathrm{~min}$ with $20 \mu \mathrm{M}$ BAPTA/AM and $0.03 \%$ Pluronic acid F-127 in a $37^{\circ} \mathrm{C}$ incubator gassed with $5 \% \mathrm{CO}_{2}$ in air, then washed twice with Ringer's solution and placed into the cuvette. Control experiments were made in presence of DMSO at $\leq 0.01 \%$.

\section{Statistical analyses}

All data represent at least 3 independent experiments and results are shown as mean \pm SEM. Statistical differences between two groups were determined by Student's t-test. Analysis of variance (ANOVA) analysis was applied for multiple group comparison. Differences were considered to be significant at $\mathrm{p} \leq 0.05$.

\footnotetext{
Abbreviations

AP3: 2-Amino-3-phosphonopropionic acid; BAPTA/AM: 1,2-Bis (2-aminophenoxy) ethane- $N, N, N^{\prime}, N^{\prime}$-tetraacetic acid tetrakis (acetoxymethyl ester); CNQX: 6-Cyano-7-nitroquinoxaline-2,3-dione; FAK: Focal Adhesion Kinase; L-THA: L (-)-threo-3-Hydroxyaspartic Acid; MAP: kinase, mitogen-activated protein kinase; MK801: (5R,10S)-(-)-5-Methyl-10,11-dihydro-5H-dibenzo [a,d] cylcohepten-5, 10-imine maleate; NMDA: N-Methyl-D-aspartic acid; t-ACPD: trans ( \pm -1-Aminocyclopentane-trans-1,3-dicarboxylic acid
}

\section{Competing interests}

The authors declare no competing interests.

\section{Authors' contributions}

AH performed experiments. GG analyzed data and performed initial experiments. PR performed experiments, analyzed data, designed the study and wrote the paper. KT coordinated the study and participated in its design. All authors read and approved the final manuscript.

\section{Acknowledgement}

This work was supported in part by grants from the Ligue Nationale Contre le Cancer (Comité du Bas Rhin). A. Hamadi and G. Giannone were supported by doctoral fellowships from the Ministère de la Recherche.

Received: 12 December 2013 Accepted: 30 April 2014

Published: 19 May 2014

\section{References}

1. Gomez TM, Snow DM, Letourneau PC: Characterization of spontaneous calcium transients in nerve growth cones and their effect on growth cone migration. Neuron 1995, 14(6):1233-1246.

2. Robles E, Gomez TM: Filopodial calcium transients regulate growth cone adhesion and motility by local activation of calpain. Mol Biol Cell 2001, 12:325a-325a.

3. Komuro $\mathrm{H}$, Rakic P: Intracellular Ca2+ fluctuations modulate the rate of neuronal migration. Neuron 1996, 17(2):275-285

4. Mandeville JT, Ghosh RN, Maxfield FR: Intracellular calcium levels correlate with speed and persistent forward motion in migrating neutrophils. Biophys J 1995, 68(4):1207-1217.

5. Renshaw MW, Ren XD, Schwartz MA: Growth factor activation of MAP kinase requires cell adhesion. EMBO J 1997, 16(18):5592-5599.

6. Renshaw MW, Price LS, Schwartz MA: Focal adhesion kinase mediates the integrin signaling requirement for growth factor activation of MAP kinase. J Cell Biol 1999, 147(3):611-618.

7. Zhang X, Chattopadhyay A, Ji QS, Owen JD, Ruest PJ, Carpenter G, Hanks SK: Focal adhesion kinase promotes phospholipase C-gamma I activity. Proc Natl Acad Sci U S A 1999, 96(16):9021-9026.

8. Giannone G, Ronde P, Gaire M, Haiech J, Takeda K: Calcium oscillations trigger focal adhesion disassembly in human U87 astrocytoma cells. J Biol Chem 2002, 277(29):26364-26371.

9. Lee J, Ishihara A, Jacobson K: Evidence for the involvement of stretchactivated calcium channels in the regulation of keratocyte locomotion. Mol Biol Cell 1996, 7:1971-1971.

10. Wu X, Mogford JE, Platts SH, Davis GE, Meininger GA, Davis MJ: Modulation of calcium current in arteriolar smooth muscle by alphav beta3 and alpha5 beta1 integrin ligands. J Cell Biol 1998, 143(1):241-252.

11. Komuro H, Rakic P: Modulation of neuronal migration by NMDA receptors. Science 1993, 260(5104):95-97.

12. Behar TN, Scott CA, Greene CL, Wen X, Smith SV, Maric D, Liu QY, Colton $C A$, Barker JL: Glutamate acting at NMDA receptors stimulates embryonic cortical neuronal migration. J Neurosci 1999, 19(11):4449-4461.

13. Kiss JZ: A role of adhesion molecules in neuroglial plasticity. Mol Cell Endocrinol 1998, 140(1-2):89-94.

14. Ye ZC, Sontheimer H: Glioma cells release excitotoxic concentrations of glutamate. Cancer Res 1999, 59(17):4383-4391.

15. Chung WJ, Lyons SA, Nelson GM, Hamza H, Gladson CL, Gillespie GY Sontheimer $\mathrm{H}$ : Inhibition of cystine uptake disrupts the growth of primary brain tumors. J Neurosci 2005, 25(31):7101-7110.

16. Ye ZC, Rothstein JD, Sontheimer H: Compromised glutamate transport in human glioma cells: reduction-mislocalization of sodium-dependent glutamate transporters and enhanced activity of cystine-glutamate exchange. J Neurosci 1999, 19(24):10767-10777.

17. Lyons SA, Chung WJ, Weaver AK, Ogunrinu T, Sontheimer H: Autocrine glutamate signaling promotes glioma cell invasion. Cancer Res 2007, 67(19):9463-9471.

18. Ronde P, Giannone G, Gerasymova I, Stoeckel H, Takeda K, Haiech J: Mechanism of calcium oscillations in migrating human astrocytoma cells. Biochim Biophys Acta 2000, 1498(2-3):273-280.

19. Shelton MK, McCarthy KD: Mature hippocampal astrocytes exhibit functional metabotropic and ionotropic glutamate receptors in situ. Glia 1999, 26(1):1-11.

20. Nakahara K, Okada M, Nakanishi S: The metabotropic glutamate receptor mGluR5 induces calcium oscillations in cultured astrocytes via protein kinase C phosphorylation. J Neurochem 1997, 69(4):1467-1475. 
21. Nakamura Y, Kataoka K, Ishida M, Shinozaki H: (2S,3S,4R)-2-(carboxycyclopropyl) glycine, a potent and competitive inhibitor of both glial and neuronal uptake of glutamate. Neuropharmacology 1993, 32(9):833-837.

22. Wong EH, Kemp JA, Priestley T, Knight AR, Woodruff GN, Iversen LL: The anticonvulsant MK-801 is a potent N-methyl-D-aspartate antagonist. Proc Natl Acad Sci U S A 1986, 83(18):7104-7108.

23. Honore T, Drejer J, Nielsen EO, Nielsen M: Non-NMDA glutamate receptor antagonist $3 \mathrm{H}-\mathrm{CNOX}$ binds with equal affinity to two agonist states of quisqualate receptors. Biochem Pharmacol 1989, 38(19):3207-3212.

24. Saugstad JA, Segerson TP, Westbrook GL: L-2-amino-3phosphonopropionic acid competitively antagonizes metabotropic glutamate receptors 1 alpha and 5 in Xenopus oocytes. Eur J Pharmacol 1995, 289(2):395-397.

25. Giannone G, Ronde P, Gaire M, Beaudouin J, Haiech J, Ellenberg J, Takeda K: Calcium rises locally trigger focal adhesion disassembly and enhance residency of focal adhesion kinase at focal adhesions. J Biol Chem 2004, 279(27):28715-28723.

26. Mandeville JT, Lawson MA, Maxfield FR: Dynamic imaging of neutrophil migration in three dimensions: mechanical interactions between cells and matrix. J Leukoc Biol 1997, 61(2):188-200.

27. Komuro H, Rakic P: Selective role of N-type calcium channels in neuronal migration. Science 1992, 257(5071):806-809.

28. Scherberich A, Campos-Toimil M, Ronde P, Takeda K, Beretz A: Migration of human vascular smooth muscle cells involves serum-dependent repeated cytosolic calcium transients. J Cell Sci 2000, 113(Pt 4):653-662.

29. Rzeski W, Turski L, Ikonomidou C: Glutamate antagonists limit tumor growth. Proc Natl Acad Sci U S A 2001, 98(11):6372-6377.

30. Stepulak A, Sifringer M, Rzeski W, Brocke K, Gratopp A, Pohl EE, Turski L, Ikonomidou C: AMPA antagonists inhibit the extracellular signal regulated kinase pathway and suppress lung cancer growth. Cancer Biol Ther 2007, 6(12):1908-1915.

31. Espinosa-Tanguma R, O'Neil C, Chrones T, Pickering JG, Sims SM: Essential role for calcium waves in migration of human vascular smooth muscle cells. Am J Physiol Heart Circ Physiol 2011, 301(2):H315-H323.

32. Munshi HG, Wu Yl, Ariztia EV, Stack MS: Calcium regulation of matrix metalloproteinase-mediated migration in oral squamous cell carcinoma cells. J Biol Chem 2002, 277(44):41480-41488.

33. Dransfield I, Cabanas C, Craig A, Hogg N: Divalent cation regulation of the function of the leukocyte integrin LFA-1. J Cell Biol 1992, 116(1):219-226.

34. Leitinger $B, M c D o w a l l ~ A$, Stanley $P$, Hogg $N$ : The regulation of integrin function by Ca (2+). Biochim Biophys Acta 2000, 1498(2-3):91-98.

35. Hu DD, Hoyer JR, Smith JW: Ca2+ suppresses cell adhesion to osteopontin by attenuating binding affinity for integrin alpha v beta 3. J Biol Chem 1995, 270(17):9917-9925.

36. Lawson MA, Maxfield FR: Ca (2+)- and calcineurin-dependent recycling of an integrin to the front of migrating neutrophils. Nature 1995 377(6544):75-79.

37. Svensson L, McDowall A, Giles KM, Stanley P, Feske S, Hogg N: Calpain 2 controls turnover of LFA-1 adhesions on migrating T lymphocytes. PLoS One 2010, 5(11):e15090

38. Bhatt A, Kaverina I, Otey C, Huttenlocher A: Regulation of focal complex composition and disassembly by the calcium-dependent protease calpain. J Cell Sci 2002, 115(Pt 17):3415-3425.

39. Franco SJ, Rodgers MA, Perrin BJ, Han J, Bennin DA, Critchley DR, Huttenlocher A: Calpain-mediated proteolysis of talin regulates adhesion dynamics. Nat Cell Biol 2004, 6(10):977-983.

40. Hendey B, Lawson M, Marcantonio EE, Maxfield FR: Intracellular calcium and calcineurin regulate neutrophil motility on vitronectin through a receptor identified by antibodies to integrins alphav and beta3. Blood 1996, 87(5):2038-2048

41. Nic D, Furuta Y, Kanazawa S, Takeda N, Sobue K, Nakatsuji N, Nomura S, Fujimoto J, Okada M, Yamamoto T: Reduced cell motility and enhanced focal adhesion contact formation in cells from FAK-deficient mice. Nature 1995, 377(6549):539-544.

42. Sieg DJ, Hauck CR, Ilic D, Klingbeil CK, Schaefer E, Damsky CH, Schlaepfer DD: FAK integrates growth-factor and integrin signals to promote cell migration. Nat Cell Biol 2000, 2(5):249-256.

43. Schlaepfer DD, Mitra SK, llic D: Control of motile and invasive cell phenotypes by focal adhesion kinase. Biochim Biophys Acta 2004, 1692(2-3):77-102
44. Parsons JT, Martin KH, Slack JK, Taylor JM, Weed SA: Focal adhesion kinase: a regulator of focal adhesion dynamics and cell movement. Oncogene 2000, 19(49):5606-5613.

45. Webb DJ, Donais K, Whitmore LA, Thomas SM, Turner CE, Parsons JT, Horwitz AF: FAK-Src signalling through paxillin, ERK and MLCK regulates adhesion disassembly. Nat Cell Biol 2004, 6(2):154-161

46. Deramaudt TB, Dujardin D, Hamadi A, Noulet F, Kolli K, De Mey J, Takeda K, Ronde P: FAK phosphorylation at Tyr-925 regulates cross-talk between focal adhesion turnover and cell protrusion. Mol Biol Cell 2011 22(7):964-975.

47. Siciliano JC, Toutant M, Derkinderen P, Sasaki T, Girault JA: Differential regulation of proline-rich tyrosine kinase 2 /cell adhesion kinase beta (PYK2/CAKbeta) and pp 125(FAK) by glutamate and depolarization in rat hippocampus. J Biol Chem 1996, 271(46):28942-28946.

48. Piao Y, Lu L, De Groot J: AMPA receptors promote perivascular glioma invasion via beta1 integrin-dependent adhesion to the extracellular matrix. Neuro Oncol 2009, 11(3):260-273.

49. Shinohara Y, Nakajima Y, Nakanishi S: Glutamate induces focal adhesion kinase tyrosine phosphorylation and actin rearrangement in heterologous mGluR1-expressing $\mathrm{CHO}$ cells via calcium/calmodulin signaling. J Neurochem 2001, 78(2):365-373.

50. Araque A, Li N, Doyle RT, Haydon PG: SNARE protein-dependent glutamate release from astrocytes. J Neurosci 2000, 20(2):666-673.

51. Araque A, Sanzgiri RP, Parpura V, Haydon PG: Calcium elevation in astrocytes causes an NMDA receptor-dependent increase in the frequency of miniature synaptic currents in cultured hippocampal neurons. J Neurosc 1998, 18(17):6822-6829.

52. Kimelberg HK, Goderie SK, Higman S, Pang S, Waniewski RA: Swelling-induced release of glutamate, aspartate, and taurine from astrocyte cultures. J Neurosci 1990, 10(5):1583-1591.

53. Szatkowski M, Barbour B, Attwell D: Non-vesicular release of glutamate from glial cells by reversed electrogenic glutamate uptake. Nature 1990, 348(6300):443-446.

54. Innocenti B, Parpura V, Haydon PG: Imaging extracellular waves of glutamate during calcium signaling in cultured astrocytes. J Neurosci 2000, 20(5):1800-1808.

55. Zonta M, Sebelin A, Gobbo S, Fellin T, Pozzan T, Carmignoto G: Glutamatemediated cytosolic calcium oscillations regulate a pulsatile prostaglandin release from cultured rat astrocytes. J Physiol 2003, 553(Pt 2):407-414.

56. Parpura V, Grubisic V, Verkhratsky A: Ca (2+) sources for the exocytotic release of glutamate from astrocytes. Biochim Biophys Acta 2011, 1813(5):984-991.

57. Liu HT, Akita T, Shimizu T, Sabirov RZ, Okada Y: Bradykinin-induced astrocyte-neuron signalling: glutamate release is mediated by ROS-activated volume-sensitive outwardly rectifying anion channels. J Physiol 2009, 587(Pt 10):2197-2209.

58. Condorelli DF, Dell'Albani P, Corsaro M, Giuffrida R, Caruso A, Trovato Salinaro A, Spinella F, Nicoletti F, Albanese V, Giuffrida Stella AM: Metabotropic glutamate receptor expression in cultured rat astrocytes and human gliomas. Neurochem Res 1997, 22(9):1127-1133.

59. Stepulak A, Luksch H, Gebhardt C, Uckermann O, Marzahn J, Sifringer M, Rzeski W, Staufner C, Brocke KS, Turski L, Ikonomidou C: Expression of glutamate receptor subunits in human cancers. Histochem Cell Biol 2009, 132(4):435-445.

60. Ye ZC, Sontheimer $\mathrm{H}$ : Astrocytes protect neurons from neurotoxic injury by serum glutamate. Glia 1998, 22(3):237-248.

61. Vandenberg RJ, Ryan RM: Mechanisms of glutamate transport. Physio/ Rev 2013, 93(4):1621-1657.

doi:10.1186/1475-2867-14-42

Cite this article as: Hamadi et al:: Glutamate involvement in calciumdependent migration of astrocytoma cells. Cancer Cell International 2014 14:42 